\title{
Historical and Political Background of Judicial Review in the Islamic Legal System
}

\author{
Dr. Nayel Musa Shaker Al-Omran ${ }^{1}$, Dr. Thabet Ahmad Abdallah Abualhaj², Prof. \\ Dato' Dr. Mohd Yakub @ Zulkifli Bin Mohd Yusoff ${ }^{3}$
}

\author{
${ }^{1}$ Department of Syariah and Management, Academy of Islamic Studies, University of Malaya \\ ${ }^{2}$ Department of al-Quran Academy of Islamic Studies, University of Malaya, 50603 Kuala Lumpur, Malaysia. \\ ${ }^{3}$ Dean of the Academy of Islamic Studies, University of Malaya.
}

\begin{abstract}
The main reason behind writing this article is because many Western and some Arab writers deny that Islamic law recognizes the principles of judicial control over the constitutionality of law in it present form. Alternatively, they allege that the concept of judicial control is simply contrary to Shari'ah. Therefore, the main question is: Does the Islamic legal system recognize the exercise of judicial review of the constitutionality of laws, especially when it comes to issues relating to constitutional matters, in their present form? Further, if this question is answered in the affirmative, what is the nature of such judicial control? This article examines judicial control over the constitutionality of laws in Islamic legal system, studying the potentiality and availability of judicial review in the Islamic legal system and civilization and investigating the historical significance of some its most important applications. This article studies the elements that have helped to establish the idea of judicial review of law in the Islamic legal system, which are the principle of separation of powers, the doctrine of the rule of law, and the independence of judicial authority in the Islamic legal system. It is limited to the study of judicial review under the Islamic legal system within Sunni Islamic jurisprudence schools, namely Hanafi, Hanbali, Shafi'i and Maliki. This article will also study judicial judgments and events that took place in Islamic history especially during the time of Prophet Muhammad (622-632 C.E.), the Pious Caliphs (632-661), the Umayyad (661-750), 'Abbasids (750-1258), the Ayyubid dynasty (1169-1252) and the Ottoman Periods (1517-1921).
\end{abstract}

Keywords: Judicial review; Constitutionality of Law; Islamic Legal System; Islamic Constitution and Legislation; Separation of powers; Rule of the Law; Independence of Judicial Authority.

\section{ESTABLISHMENT OF JUDICIAL REVIEW IN ISLAMIC LAW}

\section{INTRODUCTION}

Judicial review is the power of the courts to examine laws and executive regulations to determine whether they conform to rules and principles laid down in a specific constitution and is based on the idea that a constitution which dictates the nature, functions, and limits of a government is the supreme law. ${ }^{4}$ This article analyses the concept of judicial review in the Islamic legal systems, studies the historical and political background as well as establishment of such a review, and addresses its viability. It also raises the question as to whether the Islamic legal system recognises the principle of judicial review or not.

\subsection{Historical Background of Judicial Control in Islamic Legal System}

\subsubsection{Introduction}

The existence of some form of a judicial system or court of law has its roots in antiquity. In pre-Islamic Arabian society, litigating parties had the choice of taking their disputes to either a mutually-greed Hakam (arbitrator), an amir (tribal head) or a kahin (soothsayer possessing religious authority). Generally, cases were adjudicated based on 'urf (custom), although this was common among the clans and tribes of Arabia.5

At that time, there existed neither a unified code of law nor an executive authority which could administer justice among the different tribes of the Arabian Peninsula. Therefore, one of the greatest contributions of Prophet Muhammad was to grant Muslims revealed law and executive authority for the administration of

\footnotetext{
${ }^{1}$ Corresponding Author: nayel_shaker@yahoo.com
}

\footnotetext{
${ }^{4}$ Michael Supperston and James Goudie, Judicial Review, (London, Butterworths, 1992), 24. See also Mourice Sunkin and others, Judicial Review in Perspective, the Public Law Project, (London, 1993), ix.

${ }^{5}$ Emile Tyan, "Judicial Organization", Law in the Middle East, 1955, at 240-250.
} 
justice. The broad principles which emerged from revealed law and its implementation by the Prophet provided the foundation generations of concerned jurists to promote and develop the administration of justice. 6

\subsubsection{The Political Background of Judicial Review in the Islamic Legal System}

The principal sources of the Islamic political system, the Qur'an and Sunnah, stipulate obedience by individuals or groups to the Head of State. However, this obedience is not absolute and is restricted to conformity with the conduct of the Head of State, irrespective of whether it is legislative or administrative, with the Qur'an, Sunnah and the consensus of Shari'ah scholars on legal rulings.7 Therefore, if any government orders contradict the authority of such sources, the orders are void and should not be obeyed. There are many examples throughout history when the Islamic judiciary rejected orders, laws or decisions that were not in conformity with the Shari'ah.8

A study of judicial review of the acts of legislative authorities, whether individual or in groups, cannot be done without first studying the nature of the Islamic constitution and Islamic legislation and the manner of its implementation by the caliphs and their delegates.

\subsubsection{Nature of the Islamic Constitution and Legislation}

If judicial review was established on the principles of legality and separation of judicial authority from other public powers in a country, then the nature of the constitution and legislation in Islam has two meanings, the influence of which is reflected on that review as explained in the following paragraphs.

Nature of a constitution: The constitution in a positive legal system is a collection of legal rules that show the ruling system, its type in the country, the organization of public powers, and the obligations or duties of individuals and limitations on individual rights. This definition does not conflict with the ruling system in Islam. However, the constitution in the Islamic legal system has a deeper and more comprehensive meaning than that of the constitution in a positive legal system. The Islamic constitution is concerned with expressing faith in Allah and solidarity in implementing Allah's orders and abstinence from his prohibitions.9 Also, the Qur'an and Sunnah are the convention of Allah, the realization of interests and the repelling of harm in order to realize the aims of Shari'ah is an obligation, and ijtihad (judicial interpretation) must conform to the rules of the Shari'ah.10 Thus it differs from the constitutional rule in positive system.

There is controversy about the sources of Shari'ah among jurists, but they are generally of three main ones: Qur'an, Sunnah and al-ra'y (opinion).11 This was deduced by the former Imam of al-Azhar, Mahmud Shaltut. However, there is a group that argues that the sources are divided into two levels: the first being Qur'an and Sunnah, and the second al-ra'y (opinion) and qiyas. They also consider that the Qur'an and Sunnah are both constitutional legislation, 12 while the principles that are derived from other sources fall under the heading alra'y and are similar to normal legislation.

Nature of legislation and the domain of Shari'ah: There is a big difference between the nature of legislation in an Islamic legal system and nature of legislation in the secular one. The lawmaker in man-made systems can legislate on any matter except matters that are explicitly excluded by a particular constitution. While the legislation in the Islamic legal system must conform to the Qur'an and Sunnah, its intent must not contradict the text of the Qur'an and Sunnah. So there are several points that limit the domain of shura as legislative authority, which include the following: 13

There is agreement among scholars of Shari'ah that shura (consultation) is a kind of ijtihad in public opinion on various affairs: legislative, economic, political and social. Also, ijtihad is not allowed when there is a conclusive text in the Qur'an or Sunnah.14

\footnotetext{
${ }^{6}$ Ibid.

${ }^{7}$ MuÍammad SalÊm al-ÑAwwÉ, FÊ al-NiĐÉm al-SiyÉs $\hat{E}$ li al-Dawlah, (1983), 397.

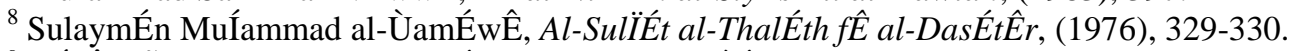

${ }^{9}$ YÉsẾn ÑUmar YËsuf, IstiqlÉl al-SulÏah al-QaİÉ iyyah, (1995), 328. See also, SulaymÉn MuÍammad alÙamÉwÊE, Al-SulïÉt al-ThalÉth, (1976), 330.

${ }^{10}$ MaÍmËd ShaltËt, Al-IslÉm: $\tilde{N} A q \hat{E} d a h$ wa SharÊẼ $a h$. (Kuwait: 1959), 398.

${ }^{11}$ Ibid. See also, SulaymÉn MuÍammad al-ÙamÉwÊ, Al-SulïÉt al-ThalÉth, (1976), 328.

12 Ibid.

${ }^{13}$ Ibid.

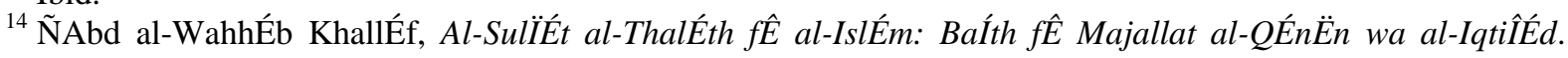
(Cairo: 1937), 565-570.
} 
Concerning the implication of non-conclusive texts, there is room for individual ijtihad, so public ijtihad would be in priori for the prevention of chaos. Such public ijtihad would take place by giving preference to certain interpretations of one text over other interpretations. 15

If there is no text of Qur'an or Sunnah or its counterpart of qiyas or ijma' (consensus of opinion), then the scope is open for shura. In this case, most of the political or governing issues derive their rules through the shura council on the basis of interest, and sadd al-dhari'ah. In other words, legislating ijtihad systems for the realisation of legislation and the organisation of administration and institutions in every subject that has no text, based on the interests of fiqh (jurisprudence). 16

Abd al-Wahhab Khallaf expressed an opinion on this point when he said that legislation has two meanings: finding new legislation, and this in Islam could not be except by Allah only; and secondly, illustrating a judgment required by existing legislation with judicial review extending to three domains of shura. Such a review extends in the first kind, decreases in the second, and dwindles in the third, and in all these kinds, the judiciary checks the conformity of legislation to the public principles of Qur'an and Sunnah and ijma'(consensus of opinion), and what the salaf agreed on as to that in which interest does not change.17

Legislative authority in the Islamic legal system encompasses several jurisdiction:.

First, the explanation of the available directives of Allah and his Messenger. While the legislative authority cannot replace or change or amend them, it is competent to sort them in legislative sections, devise relevant definitions and details, and make rules and regulations for the purpose of enforcing them.

Second, the provisions and injunctions in the Holy Qur'an and Sunnah construed and interpreted, in the same instance, in various ways. So, it is up to the legislature to choose which interpretation is to be brought into operation.

Third, if there were no explicit provisions in the Holy Qur'an and Sunnah pertaining to a subject, it is incumbent on the legislature to enact laws pertaining to that subject in line with the spirit of Islamic and public interest.

According to Sayyid Qutb, "Any action by any human government has to be measured against the requirements of the Shari'ah, and any man-made rule, policy, or regulation that contradicts any provision of the Shari'ah is invalid."18

Rashid al-Ghannushi said that Islam makes the binding nature of provisions a basis for legitimacy of the state and makes a ruler bound by the decisions he takes, and the procedures and the commands he issues- through the provisions of the Shari'ah.19

Tawfiq al-Shawi considered that all the organisations, institutions, and individuals who represent (the Islamic state) must be bound to comply with the principles of the Shari'ah and apply them to themselves and by their own exercise of authority before they apply them to the general population and the individuals within society. 20

'Awdah wrote that "Islam forbids each Muslim from obeying a law or command that violates the Shari'ah of Islam and exceeds limits established by God and his prophet." Positive legislation thus has a sharply limited role. Such legislation can only exist where the Shari'ah is silent and there are no particular relevant texts, and such legislation must agree with the general principles of Shari'ah and its legislative spirit.21

\section{ELEMENTS OF THE EMERGENCE OF JUdicial CONTROL}

There are several factors in the emergence of judicial control, pre-eminent among which are the principle of the separation of powers, the doctrine of the rule of law and judicial independence. This article will address these elements in the Islamic legal system.

\footnotetext{
15 Ibid, 577.

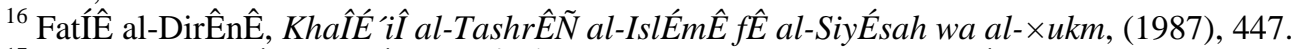

${ }^{17} \tilde{N}$ Abd al-WahhÉb KhallÉf, Al-SÊyÉsah al-SharÑiyyah, (Kuwait: DÉr al-Qalam, 1988), 49.

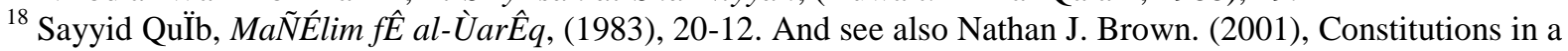
Nonconstitutional World, State University of New York Press, p166.

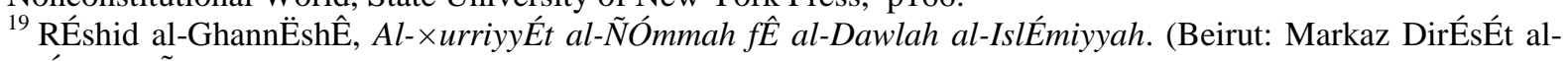
WiÍdah al-ÑArabiyyah, 1993), 105. And see also Nathan J. Brown. (2001), Constitutions in a Nonconstitutional World, p170.

${ }^{20}$ TawfÊq al-ShÉwÊ, Fiqh al-ShËrÉ wa al-IstishÉrah. (el-Mansura: DÉr al-WafÉ', 1992), 168-170. And see also Nathan J. Brown. (2001), Constitutions in a Nonconstitutional World, p169.

${ }^{21}$ ÑAwdah, ÑAbd al-QÉdir, Al-IslÉm wa al-WaİNiyyah al-QÉnËniyyah. (Beirut: Mu'assasat al-RisÉlah, 1951), 61. And see also Nathan J. Brown. (2001), Constitutions in a Nonconstitutional World, p166.
} 


\subsection{Separation of Power in the Islamic Legal System}

Many jurists of Islamic and modern law opine that the Islamic legal system recognises the principle of separation of powers, and the predominant opinion of Islamic jurists also holds that the emerging Islamic legal system knew the principle of separation of powers in the country's legislative, executive and judicial branches, but all these powers were governed by the Prophet Muhammad and his four orthodox caliphs. 22

In the early days of Islam, the principle of separation of powers was applied when Prophet Muhammad first invested judicial powers in a provincial government then later appointed a judge who was independent of any political or administrative consideration.23 After the conversion of Arabia, when a large number of people came under the sway of Islam, the Prophet Muhammad appointed various functionaries for the different parts of the peninsula. Whenever a governor or a military commander was appointed, the caliphs followed the example of the Prophet and usually appointed a judge as well, over whom these officials had no jurisdiction. 24

There are many examples of this practice in the Sunnah of the Prophet Muhammad and the caliphs. It is reported that the Prophet of Islam asked Mu'adh ibn Jabal questions upon the latter's appointment as judge to Yemen, in answer to which Mu'adh told the Prophet that he would resort to his own ijtihad in the event that he failed to find guidance in the Qur'an and Sunnah, and the Prophet was pleased with this reply, and patted him on the chest and said, "Praised be God, who has caused the messenger of God's Messenger to please the latter!"25

When he [Mu'adh ibn Jabal] was being sent [as governor] to the Yemen, the Prophet asked him: "How will you decide the cases that will be brought before you?" Mu'adh replied: I shall decide them according to the Book of God." - "And if you find nothing concerning [a particular matter] in the Book of God?" - "Then I shall decide according to the Sunnah of God's Apostle." - "And if you find nothing about it in the Sunnah of God's Apostle?" - "Then," replied Mu'adh, "I shall exercise my own judgment [ajtahidu bi-ra'yi] without the least hesitation." Thereupon the Prophet slapped him upon the chest and said: "Praised to be God, who has caused the messenger of God's Messenger to please the later!'1

Through the above mentioned example, it is obvious that two basic rules are confirmed:

First: Written law, when the Muslim judge neither gives his judgment according to custom and usage nor on the basis of an order given to him by the caliph or the ruler, but rather gives his judgment according to the Qur'an and Sunnah, and if he does not find any rule in them, he gives his opinion on the basis of his own ijtihad.

Second: The judiciary in Islam is an independent authority that is not subordinate to any particular person. The judge rather follows the texts before him, firstly the Qur'an and then the Sunnah and only after these does he use the inspiration of his conscience, understanding and discernment in order to arrive at justice.

There is a relationship between the judicial and executive authorities with respect to appointment and dismissal, but without any subsequent interference with the judiciary's primary function which is to hear and decid cases and disputes.

There are many events which happened in Islamic history in which the principle of separation of powers was applied. After being chosen as the first caliph, Abu Bakr invested 'Umar with judicial powers. During 'Umar ibn al Khattab's caliphate, he was the first to directly charge other persons to exercise the functions of a judge. He appointed Abu Darda' as a judge with him in Medina, Shurih as a judge in BaÎrah and Abu Musa al-Ash'ar' as a judge in Kufah.26

There is the story of Mu'awiyah, the governor of Sham and 'Ubadah ibn al-Samit, the judge of Palestine and Jordan, as narrated by al-Awza'i. "The first to take the position of judge in Palestine was 'Ubadah ibn al-Samit, and Mu'awiyah refused to execute a ruling by 'Ubadah who stood by his decision. So Mu'awiyah spoke aggressively to him, and 'Ubadah said, he would never again live with Mu'awiyah in the same area, and he left

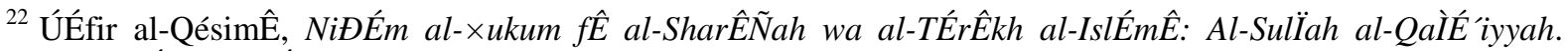
(Beirut: DÉr al-NafÉ'is, 1974), 403.

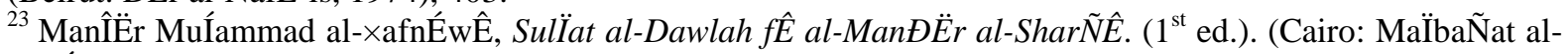
AmÉnah, 1989), 349.

${ }^{24}$ Anwar Ahmad Qadri, Justice in Historical Islam, (Lahore: SH Muhammad Ashraf, 1968), 8. See also ÚÉfir

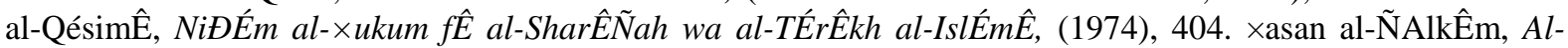

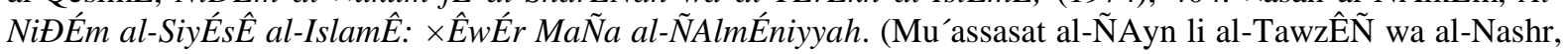
1991), 178.

${ }^{25}$ Sunan $A b \hat{E} D E ́ w \ddot{E} d$. (Beirut: DÉr al-Kutub al-ÑIlmiyyah, 2001), xadÊth no. 3592. See also, Mohammad Hashim Kamali, Principles of Islamic Jurisprudence, (Kuala Lampur: Ilmiah Publishers, $2^{\text {nd }}$ edn., 1998), 45, 217 and 218 .

${ }^{26}$ Ibid, 18. 
for Medina. When 'Umar asked what brought him here, 'Ubadah told the caliph what had happened. 'Umar replied, "Go back to your position, repugnant is a land in which you and your likes are not." Then "Umar wrote to Mu'awiyah and told him, "You have no authority over 'Ubadah."27

This story highlights that 'Umar ibn al-Khattab emphasised the separation between the judicial authority and the executive authority, and made a direct relationship between the caliph and the judge. Thus, since the seventh century C.E., the principle of separation of powers, and especially the independence of the judiciary and its separation from the other authorities has been established in an Islamic country, while contemporary nations only recognised this in the late eighteenth century.

The story of the conquest of Samarqand is a unique one in human history and illustrates the clear understanding of the early Muslims of the principle of separation of powers and its implementation.

The people of Samarqand said to Sulayman ibn Abi al-Sirri, the governor appointed by 'Umar ibn 'Abd al'Aziz, that Qutuba ibn Muslim, the military leader, had deceived and oppressed them and took their country, and since Allah has shown justice and equity, allow us to send a delegation to the Commander of the Faithful (Amir al-Mu'minan) to complain about the injustice towards us, that if "we had a right we shall have it for we need it." So he allowed them. Thus they sent a delegation that met with the caliph, who then wrote for them to Sulayman ibn Abi Sirri, asking him to appoint a judge to look into their grievance. The judge Jumai' ibn Hadir was appointed, and he ordered that the Arabs of Samarqand leave and return to their camp."

The author observes that 'Umar ibn 'Abd al-'Aziz fully recognised the principle of separation of powers. That is because when he knew the grievance of the people of Samarqand, he did not decide the case himself, although he could have as he was the caliph of Muslims. In addition he did not entrust the governor of Samarqand, with the settlement of the case, fearing that he might be biased. Further, because he was the governor appointed by the caliph, 'Umar refused to let him decide the case, and neither did he authorise the military leader who committed the offence against the rules of the Shari'ah. Rather, he ordered that a judge who was not affected by military or political interests be appointed, and he did not give any consideration except for the rule of Allah, to enforce the rules of Shari'ah as they are stated.

The above sample cases indicate the separation of powers during different periods of Islamic history, especially during the Umayyad and Abbasid periods where this principle was practically implemented.

\subsection{The Rule of Law in the Islamic Legal System}

The principle of the rule of law means that the ruler and the ruled submit to the rule of law. This principle became stable through the struggles of people against tyranny, injustice and absolutist authority that was not restricted or limited by any bounds. One such example is the struggle of the people in the French revolution, which took place in 1789.

While the principle of the rule of law in the Islamic legal system was considered as the basis or cornerstone on which Islam was founded, as Creed and Shari'ah, because Islam was revealed to remove injustice, fight tyranny and demolish the pillars of absolutist authority. That principle has its basis in the Qur'an, Sunnah and the consensus (ijma') even during the centuries that people grappled with despotism. 28

Allah says: "And if any fail to judge by (the light of) what Allah hath revealed, they are (no better than) wrongdoers".29

He also says: "Let the people of the Gospel judge by what Allah hath revealed therein. If any do fail to judge by (the light of) what Allah hath revealed, they are (no better than) those who rebel." 30

And in another verse, He says: "If any do fail to judge by (the light of) what Allah hath revealed, they are (no better than) Unbelievers." 31

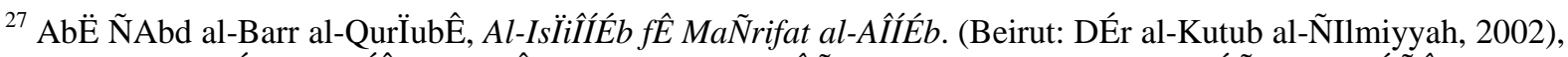

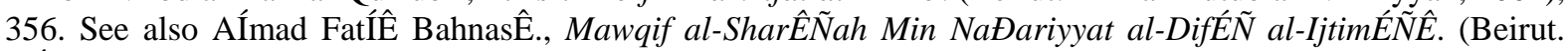
DÉr al-ShurËq, 1984), 3.

${ }^{28}$ YÉsÊn ÑUmar YËsuf, IstiqlÉl al-Sul̈̈ah al-QaİÉ iyyah, 298. See also Al-MaÑhad al-ÑólamÊ li al-Fikr alIslÉmẾ, Al-Dawlah: Al-Fikrah wa al-ArkÉn wa al-Mu'assasÉt. (U.S.A: Grove Street Herndon, 1981), 66-67. See also ÖiyÉ' al-DÊn MuÍammad al-Rayyis, Al-NaĐariyyÉt al-SiyÉsiyyah al-IslÉmiyyah. (Cairo: Maktabat DÉr al-TurÉth, 1976), 365-375.

${ }^{29}$ Abdullah Yusuf Ali (trans.), The Qur'Én, Text, Translation and Commentary, (Jedda: Islamic Education Center. Reprint by the Muslim Converts Association of Singapore, 1984), SËra, 5, 44. See also xasan al-

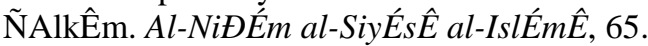

${ }^{30}$ Abdullah Yusuf Ali; al-(trans.), The Qur'Én, Text, Translation and Commentary Qur'Én 5: 45.
} 
In other verse, Allah says: "O ye who believe! Obey Allah, and obey the Messenger, and those charged with authority among you. If you differ in anything among yourselves, refer to Allah and His Messenger, if you do believe in Allah and the last Day: that is best, and most suitable for final determination." and the following verse, where Allah says: "O ye who believe! Obey Allah. And obey the Messenger, and make not vain your deeds!"32." Therefore, the Muslim judge must implement Qur'an and Sunnah in every dispute brought before him, but if he does not implement that, his conduct will be annulled33

The Sunnah supports, emphasises and clarifies these Qur'anic verses. As Prophet Muhammad said, "Obedience of a human being is disallowed, if it is considered disobedience to the creator (Allah)." He also said, "Hearing and obeying is binding on a Muslim, whether he likes or dislikes the order - so long as he is not ordered to commit a sin; but if he is ordered to commit a sin, there is no hearing and no obeying." 34 And further, "No obedience is due to him who does not obey God" 35 and "Every act that does not conform to our order is rejected."36

In the Islamic legal system, everyone, from head of state to government to the masses, is subject to the law. The Prophet of Islam himself was subject to it, and was the most obedient person to the Qur'an. He was "'Abd Allah wa rasaluh," the servant of God and His Messenger. Under the Islamic legal system, the head of state cannot invoke any immunity from impeachment. The principle, "Be you ever so high, the law is above you," has always been there in Islamic law. Just before he died, the Prophet of Islam made the following short speech:

"I swear by God that I have made lawful only those things that the Qur'an made lawful and I have made unlawful only those things that the Qur'an made unlawful. If I have taken the money of any of you, here is my money, let him come and take it, and if I have lashed the body of any, here is my body, let him take back his right. 37

The verses, supported by ahadith (translation?) indicate that every dispute that happens in Islamic society between individuals, between groups of people, or between people and the government, or among parts of the government and its people, must be judged by the fundamental law which has been received from Allah and His Messenger. According to this principle, an Islamic country must have an institution that judges among people according to the Qur'an and Sunnah, and that institution is the judicial authority.38

In the same way, Abu Bakr, the first successor and caliph of the Muslim state, in his acceptance speech said:

O people! I have been appointed over you, but I am not the best of you. Support me if I do good and remove me if I do badly... a weak person among you is strong before me as long as I maintain his right for him. And a strong one among you is weak before me until I take back a right from him... Obey me as long as I obey Allah and His Messenger. If I disobey them, there is no obedience of me upon you.39

To illustrate respect for justice, an example can be found in one of the transactions that 'Umar ibn al-Khattab entered into, when he purchased a horse and on approval, allowed a rider to try it. The horse was injured in the course of the ride, and the caliph wanted to return the horse, but the owner refused to take it back. The dispute was referred to the judge who observed, "If the horse was used for the purpose of riding with the permission of

${ }^{31}$ ×asan ÑAlkÊm, 65. See also MuÍammad YËsuf MËsÉ, NiĐÉm al-×ukm f̂̂E al-IslÉm. (Cairo: DÉr al-KitÉb al-ÑArabÊE, $2^{\text {nd }}$ edn., 1964), 74.

32 TirmidhÊ, al-JÉmi Ñ al-ØaÍẾ, Vol 1: 319. See also ÖiyÉ' al-DÊn MuÍammad al-Rayyis, Al-NaĐariyyÉt alSiyÉsiyyah al-IslÉmiyyah, (Cairo, 1967), 340.

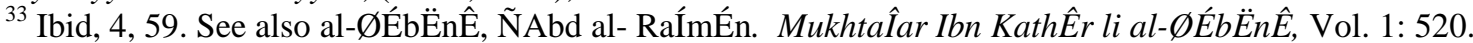

${ }^{34}$ AbË ÑAbd Allah MuÍammad ibn IsmÉÑ̂̂l BukhÉrÊ, KitÉb al-JÉmiÑ al-ØaÍ̂́Í, Vol. 9: 52. See also AbË alxusayn ibn al-×ajjÉj al-NÊsÉbËrÊ Muslim, (n.d.). ØaÍẾI Muslim. n.p. Ed.m.), 111. Sunan al-TirmidhÊ. See also Mohammad Asad, The Principles of State and Government in Islam, (Cibraltar: Dar al-Andalus 1980), 34, 26. See also ÖiyÉ' al-DÊn MuÍammad al-Rayyis, Al-NaĐariyyÉt al-SiyÉsiyyah al-IslÉmiyyah. (Cairo:

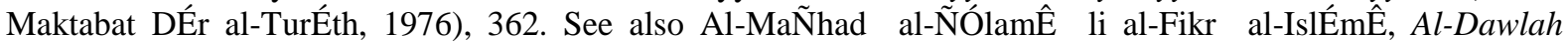
(1981), 84,85

${ }^{35}$ Aímad Ibn ×anbal, Al-Musnad: Musnad al-AnîÉr. Vol. 7. (Beirut: DÉr ÑÓlam al-Kutub, 1998), 540.

${ }^{36}$ MuÍammad MuÍsin KhÉn, (trans.), ØaÍẾI al-BukhÉrÊ. Vol. 3, (1970), 535-536.

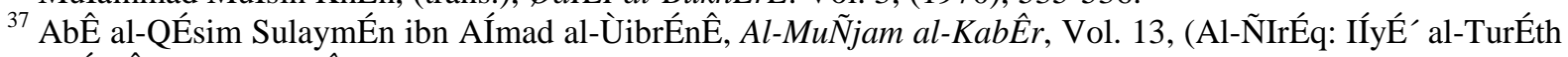

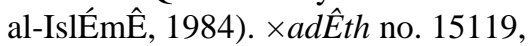

${ }^{38}$ MuÍammad ibn Khalaf ibn ×ayyÉn WakỄ̃̃, AkhbÉr al-QuİÉt. (1 ${ }^{\text {st }}$ ed.). (Beirut: ÑÓlam al-Kutub, 2001$), 357$.

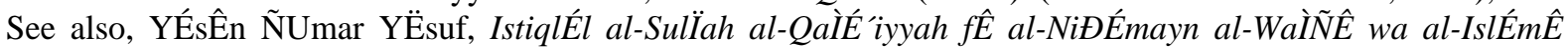
(1995), 300.

${ }^{39}$ AbË MuÍammad ÑAbd al-Malik Ibn HishÉm, SÊrat al-Nab̂̂E MuÍammad. Vol. 3. (Cairo: Maktabat DÉr alTurÉth, 1980), 340-341. 
the owner, it could be returned, otherwise not!" The caliph was pleased with the judgment and promoted the judge as the qadi of al-Kufah.40

In the application of the principle of legality, which is one of the foundations of the Islamic legal system of rule, the Muslim rulers, after the first Islamic century, implemented the same principles of Shari'ah that were applied by their predecessors. So, a ruler submitted to the rules of the judiciary as an ordinary individual. Also, always in his conduct and deeds, he tried to implement the Islamic legal system. Thus the principle of legality was not a mere personal method but a principle that stabilised in the conscience of people, and has existed since the establishment of the Islamic government.41

Muhammad Salam al-'Awwa discussed the Medinan polity as the world's first State: The Islamic state in Madinah was the oldest example of a political society organised in the form of a 'state'. This claim rests on the fact that it was an organised society based on the 'rule of law', the supremacy of which is a distinguishing factor between a 'state', and other forms of organised political societies. It presupposes that all organs and agencies of a government are subject to and will abide by the rule of the same legal system which governs the individual citizen.42

Diya' al-Dan al-Rayyis says that none of the Muslim rulers and Jurists dispute that obedience is not allowed except in conformity with the Shari'ah, Qur'an and Sunnah, and no one ever said that obedience is allowed in transgression.

It is clear that the principle of the rule of law in the Islamic legal system was the cornerstone on which the independence of the judicial authority was based. So if this principle had started politically in the secular system as a result of the struggle of the people against absolutism, then it subsequently became a legal principle in its essence. This contrasts with the Islamic legal system, when the principle of validity started as a legal principle and the main centre for 'aqadah (Creed) and the Shari'ah, from the early days of the Islamic government's missionary work, because law is divine.

Muslim judges rejected the application of any law, order or decision which was passed by the caliph or his officers, if that law, decision or order contradicted the general principles of the Qur'an and Sunnah. The Islamic legal system thus recognised the principle of the rule of law and the independence of the judicial authority, as a natural result of this, preceding its recognition in the positive system by several centuries.

\subsection{Judicial Independence in the Islamic Legal System}

Judicial independence must be a principle of an Islamic constitution. No person in an Islamic State, not even the elected Head, can be above the law, and as such, he is subject to the Hudud "punishments for major crimes" just like anyone else. The Qur'an repeatedly enjoins the administration of justice in an impartial manner, even though the decision may go against a judge's own kinsmen or his own community.43

Emile Tyan mentions that, a Muslim judge does not have an independent or even autonomous position, especially during the early stages of the establishment of the Islamic state. He adds that the then head of state (the caliph) derived his judicial power from no one but subordinates by virtue of his position. Tyan also asserts that the concept of delegation in Islam was the complete lack of separation of the judicial authority from the executive authority. 44

It appears that during the period of the pious caliphs, the judicial system was independent and integral. The judge had no register in which his judgments were recorded, because those judgments were carried out by the judge himself.

During the Umayyad period, Muslim law was characterised by two main features: First, the judge ruled according to ijtihad, because the four schools of Muslim law, by which judges had to abide, were not established until the early 'Abbasi period. He drew his own judgment from the Qur'an and Sunnah, or the ijma' (consensus), or his own discretion (qiyas). 45 Second, the judge was not influenced by politics; he was

\footnotetext{
${ }^{40}$ Anwar Ahmad Qadri, Justice in Historical Islam, 23.

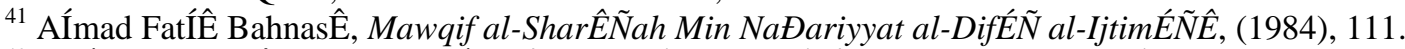

${ }^{42}$ MuÍammad SalÊm al-ÑAwwÉ, FÊ al-NiĐÉm al-SiyÉsÊ li al-Dawlah al-IslÉmiyyah. (Cairo. al-Maktab alMî̂t̂̂ al-×adÊth, 1983), 1.

${ }^{43}$ Farooq Hassan, The Concept of State and Law in Islam, University Press of America), 65. See also AÍmad xasan, "The Political Role of IjmÉÑ," Islamic Studies, Journal of the Islamic Research Institute, (Pakistan, Vol. VIII, No.1, 1969), 188.

${ }^{44}$ Emile Tyan,"Judicial Organization.” Majid Khadduri. (ed.). Law in Middle East, 1955), 236.

${ }^{45}$ Mahmud A. Faksh, "A Review of Islamic Culture," The Islamic Quarterly, Vol. xxviii (Number 1), (England: The Islamic Culture Centre, 1984), 110.
} 
independent in his judgment, far from being influenced by the ruling dynasty. His authority was unlimited and the governors of the provinces, the collectors, and even the caliph had to submit to his judgment.46

During the 'Abbasi period, several important characteristics were established in the judiciary system:47 First was the appointment of judges representing the four orthodox schools in each province. Each of these judges was entrusted with the task of dealing with cases related to the persons who adhered to the teaching of their particular school. Secondly, the system of permanent, trustworthy witnesses after verifying their good character from the outward, without regard to their hidden character, was introduced. Finally, a remarkable improvement was the registers, in which matters related to legacies and debts were recorded.48

In one of his articles, N. J. Coulson writes that the qadi (judge) appeared in early Umayyad times as legal secretaries of the governor. And these were delegated, through appropriate measures, to the subordinate state officials. N. J. Coulson also asserts that the political authority, which defined the scope and nature of the qadi's jurisdiction, and naturally the decisions given and actions taken by the qadi, were subject to the approval or otherwise of the governor.49

Islamic history has many eminent judges who were distinguished by their faith, strong belief, manners, morals, dignity, knowledge, deep wariness of rules, courage and independence. Many of them stood fast against the interference of the executive, firmly and determinedly rejecting all kinds of direct and indirect influence or orientation. Marvellous was their courage, dignity and readiness to resign as soon as they were exposed to pressure from rulers, relatives, friends, or assistants.

During his life, Prophet Muhammad was the leader and chief judicial authority in the Islamic State. However, he also appointed several close companions to assist him in the administration of the law.50

During the reign of the Rashidan caliphs, the judicial authority took a form similar to that in the period of the Prophet of Islam. There was no demarcation of judicial authority with that of other powers. The Rashidan caliphs upheld and respected the independence of the judiciary, especially 'Umar and 'Ali who had occasion to appear and plead their cases before the qadi like any other parties to litigation, and both of whom exhibited sensitivity and concern not to be given preferential treatment in court. The fact that a qadi would accept a suit against the person of the head of state and try him in an open court is a feature of the Islamic judiciary and an indication of its independent status. 51

However, there was a significant change in the period of the Umayyad and the 'Abbassi caliphates. The judges enjoyed freedom especially in the exercise of independent ijtihad. Moreover, caliph Mu'awiyah was the first to abdicate all his judicial powers to appointed judges. The judiciary was completely independent from the executive authority without any exceptions.52

In the 'Abbassi period, during this period, there was a specially appointed person who was called qadi al-qudah. Harun al-Rashid was the first caliph to be appointed to the office of qadi al-qudah, and Abu Yusuf was the first chief judge (qadi al-qudah) appointed by him. In addition, Harun al-Rashad did not appoint any judge without consulting Abu Yusuf (the delegated head of judiciary), and the qadi exercised judicial authority in the capacity of a Hakim (ruler), not a muwaddaff (task of al-quìah officer).53

\footnotetext{
${ }^{46}$ Hassan Ibrahim Hassan, "Judiciary System from the Rise of Islam," at 567. (C.E.1171). Ali Abd Al-Kader, The Islamic Quarterly, A Review of Islamic Culture, VI Numbers 1, 2, (England: the Islamic Culture Centre, 1961), 26-27.

${ }^{47}$ Ibid. See also Ahmad Ibrahim, "The Shariah Court and Its Place in the Judicial System," International Islamic Conference on The role of Judiciary in The Development of Islamic Law, November 21 St- 23 ${ }^{\mathrm{RD}}$ (1986), Malaysia, 70.

${ }^{48}$ Hassan Ibrahim Hassan, "Judiciary System from the Rise of Islam," at 567. (C.E.1171). Ali Abd Al-Kader, The Islamic Quarterly, A Review of Islamic Culture, VI Numbers 1, 2, (England: the Islamic Culture Centre, 1961), 24.

${ }^{49}$ N. J. Coulson, "Doctrine and Practice in Islamic Law," Bulletin of the School of Oriental and African Studies, 214.

${ }^{50}$ Masudul Hasan, Reconstruction of Political Thought in Islam, (Pakistan: Islamic Publications (PVT) Limited, 1988), 207.

${ }^{51}$ Mohammad Hashim Kamali, “Appellate Review and Judicial Independence in Islamic Law,” Chiblis Mallat and Graham Trotman, Islamic and Public Law, 1993), 53-54.

52 Ibid, 55.

${ }^{53}$ Ibid, 36-37.
} 
Judicial independence is considered a healthy development to meet contemporary demands and needs. It made the role of the judicial authority more prominent and effective in the Islamic state, and although judicial authority changed hands, the caliph was still largely responsible for maintaining the judiciary institution.

\subsection{Availability of Judicial Review in Islamic Legal System}

When making his decisions, a judge should rely on the Qur'an, the Sunnah of the Prophet of Islam and consensus, and if he does not find any (ruling), he should exercise ijtihad to derive a Shari'ah ruling from other evidence, in order to apply it to the facts before him (Judge).

What can be conceived in the field of judicial review over the constitutionality of laws, as far as Shari'ah is concerned, is that it is implemented on legislation passed by a parliament, which is known as (Ahl al-Hall wa al'Aqd). Legislation here is solely based on ijtihad, because the definitive rulings that are found in the Qur'an and Sunnah are considered constitutional texts over which the judge has no review, and what has been passed by way of consensus is infallible and there is no review over that as well. However, a review can be conducted on rulings of the source which is ijtihad.54

One of the functions of 'parliament' is ijtihad and legislation, and it uses juridical interpretation in cases where there exists no text from the Qur'an or the Sunnah or consensus in order to derive a Shari'ah ruling. If such derived rulings are drafted as laws for the judiciary to implement, then the judicial review over the constitutionality of law and their legitimacy would be required because the judge in the Islamic legal system is not allowed to implement a law which he sees as conflicting with the Qur'an and Sunnah.

In the Qur'an, there are two kinds of verses, namely absolute and presumptive, the latter being those which are capable of different interpretations. The decisive verses are the basis of the Qur'an and contain the fundamental principles of religion. So, whatever the differences of interpretation over allegorical verses may be, the fundamentals of religion are not affected by them. 55

The Supreme Constitutional Court of Egypt has articulated this principle on numerous occasions. In 1996, for instance, a father brought a case to the Court involving an administrative decree issued by the Minister of Education barring female students from wearing niqab "a veil covering the full face in contra-distinction to the permitted Hijab, a veil covering only the hair" in state schools. The proponents of Shari'ah-based constitutional jurisprudence seemed to have a strong case. The challengers cited not only Article 2, of the Egyptian constitution of 1971, but also the personal rights provisions of the constitution. The father claimed that the minister's decree violated both the Shari'ah and rights of a liberal provenance. The court rejected the claim, however, laying out once again the view that grants executive and legislative authorities tremendous latitude:

It is not permitted for a legislative text to contradict those shura provisions definitive in their certainty and meaning (qat'i al-thubut wa-al-dalalah). These rules alone are those for which ijtihad is forbidden because they signify the comprehensive principle and fixed roots of the Shari'ah, accepting neither interpretation nor substitution... [The judgments based on reason] are more protective of humanity's true interests, which the [shura] provisions are prescribed to realise in terms of what is appropriate for these interests. The underlying factor is that the essence of God's Shari'ah is truth and justice. Being limited by the Shari'ah is better than widespread depravity. 56

It is not permitted to hold [such opinions] to be firm, settled Shari'ah law that cannot be contravened. To do so would be to end contemplation of and reflection over Almighty God's religion; it would deny the truth that error possible in all ijtihad. The challenged decree does not contradict...the text of article 2 of the constitution. The rule has in debatable questions - the right of ijtihad to facilitate the affairs of the people and reflect what is authentic in their customs and traditions, so long as over-arching purposes of their shura is not abrogated ....

An attempt to use Article 2 of Egyptian constitution of 1971, as the basis for the application of a Shari'ah-based law must now overcome one of two hurdles. First, one might resort directly to the Court. Yet, by rejecting any claim that is not a clear and permanent injunction of the shura, the Court has made this barrier formidable. Others have distinguished between unalterable sources of law - the Qur'an and Sunnah - on the one hand, and those based on human judgment on the other.

The jurists have the right to make sure that ijtihad, which is a brainstorming process to deduct practical rules to regulate the life of people, in the non-peremptory provisions is achieving their interest. Hence ijtihad should

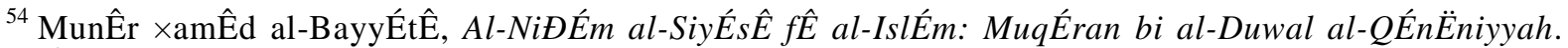
$\left(2^{\text {nd }}\right.$ Print). (Amman: DÉr al-BashÊr, 1994), 281.

${ }_{55}^{5}$ Farooq Hassan, The Concept of State and Law In Islam, 36.

${ }^{56}$ Case 8, judical Year 17, issued by the Supreme Constitutional Court 18 May, 1996. see also Egyptain Constitution of 1971 (Egypt)
} 
cope with the context of events prevailing at the time. It does not have a binding power but on those who believe in it. This sign of God's mercy permits different ijtihad to encourage people to think and avoid the possibility of human error. Thus, the Shari'ah is always developing and flexible to accept the ijtihad of responsible individuals to achieve the utmost interest of the people.

A number of Muslim jurists have shown that the Islamic legal system has, in theory, recognised the review system over the constitutionality of law, but does not practice it. Among them is the Muslim scholar Abu alA'la al-Mawdudi who writes:

Does Islam permit the judiciary to reject some legislation that is passed by the legislative council as being contradictory to the Qur'an and Sunnah? I did not look into a text under this topic and there is no doubt that what the work of the orthodox caliphs (al-Khulafa' al-Rashidin) indicate that the judiciary had no such powers. At least we have not found until now an example of this matter, but the reason for this, as I see it, is that all the members of parliament (Ahl al-Hall wa al-'Aqd) were at that time very knowledgeable in the Qur'an and Sunnah, and above them were the orthodox caliphs who did not pronounce in any way on an issue that was in contradiction to the Qur'an and Sunnah.57

Although the author agrees with many aspects of this opinion, he is of the view that the legislative council consists of normal people who are human beings and are affected by matters that all people are affected by. So, mistakes may be made according to the circumstances, and the promulgation of legislation that is not in conformity with the Qur'an and Sunnah is not an impossible proposition. On the contrary, it is conceivable. The objective behind the promulgation of such legislation is not the contradiction of the Qur'an and Sunnah per se, but might rather be caused by the absence of discernment or the actual purpose of its promulgation.

The Islamic legal system, during the period of the four pious caliphs, did not recognise the principle of judicial review over the constitutionality of laws or acts. There was no room in Islam for the judiciary to reject or to restrict the powers of the caliphs in respect of enacting laws in contravention of the Qur'an and Sunnah. During this period, the judiciary did not enjoy or exercise such powers and there was no instance of any qadi (judge) taking such an action. This is because the members of the legislative authority at that time had a very deep and true insight in the Qur'an and Sunnah and all the four pious caliph were the most reliable persons in all respects. In addition to that, under their authority, there was no real danger of any such legislation taking place which was contrary to the spirit of the Qur'an and Sunnah.

The principle of judicial review over the constitutionality of laws appeared after the end of this period, giving the judicial authority the right to declare void, and ultra vires of a constitution, all laws and legislation enacted in contravention of the Qur'an and Sunnah.

Perhaps, the best example to be given here is when Caliph 'Umar ibn al-Khattab (may Allah be pleased with him) refused to divide the conquered lands of Iraq among the conquerors while most of the Prophet's companions, who formed the legislative council (Ahl al-Hall wa al-'Aqd), were asking for the division and the most eager amongst them was Billal ibn Rabah. But 'Umar was able to convince them, using evidence from the Qur'an and Sunnah and by showing the wisdom behind the refusal of such a division among the conquerors, which was the fear of cessation of Islamic conquest and the defence of the wide Islamic State. He also explained to them that the decision not to divide was not based on his own desire, but was rather in agreement with the Qur'an and Sunnah.58

Thus we can say that the Islamic judiciary has the power to reject any law that is not in conformity with the Qur'an and Sunnah. Moreover, the judge is bound, in exercising his function of giving a judgment, by what Allah has revealed. The Prophet said: "you should not obey any human and thereby disobey the Creator"59 and Allah revealed: "... If any do fail to judge by (the light of) what Allah hath revealed, they are Unbelievers."60 This shows that the Islamic legal system did require review of the constitutionality of law before positive law systems implemented it.

Furthermore, the right of review that the judiciary has over the constitutionality of law, the source of which is ijtihad, is not absolute, as a judge may not merely claim that a law contradicts the Shari'ah. This is because the juridical interpretation that emanates from people who have the correct mechanism of juridical interpretation, and the law that is promulgated on its basis and is met by the approval of the leader after its promulgation, must

\footnotetext{
${ }^{57}$ AbË al-AÑlÉ al-MawdËdÊ, TadwÊn al-Dust ̈̈r al-IslÉmÊ. (Saudi Arabia: DÉr al-SaÑËdiyyah, 1985), 61.

${ }^{58}$ AbË YËsuf YaÑqËb IbrÉhÊm, KitÉb al-KharÉj. (Beirut: DÉr al-MaÑrifah, 1970), 28-38.

${ }^{59} \mathrm{Al}-\mathrm{Bayhaq} \hat{E}$, al-Sunan al-KubrÉ, Vol. 3: 122. See also Sunnan al-NasÉ' $\hat{E}$ : KitÉb al-QaİÉ'.

${ }^{60}$ Abdullah Yusuf Ali (trans.). (1984). The Qur'Én, Text, Translation and Commentary, al-Qur'Én 5: 44.
} 
be implemented by the judge even if it contradicts the judge's own interpretation. It is a well established legal maxim in the science of jurisprudence that one judicial interpretation does not become overruled by its like. 61

Among the most important jurists who talked about review of the constitutionality of law is Ibn Hazm alAndalusi, who said, "No ruling is permitted unless it is based on what Allah has revealed to His Prophet Muhammad and it is the truth, and all that is not, is considered injustice and tyranny, and any ruling based on it is not permitted and must be annulled if a judge ruled by it."62 Ibn Hazm supported his view with some verses of the Holy Qur'an, such as the revelation of Allah: "... and any who transgresses the limits of Allah, does verily wrong his (own) soul..."63 and "the approval of injustice may not be permitted and the wrong may not be let to pass."64

It is to be noted that even though rules based on ijma' (consensus of opinion) and ijtihad (independent judgment) are not directly based on the Qur'an and Sunnah, these rules must be in conformity with the principles and spirit of shura which is directly derived from the Qur'an and Sunnah.

Abu Hanifah said, "If I said non-conformity with the Qur'an and Sunnah of the Prophet, do not take my saying."65

He also said, "It is not permissible to anyone to adopt our opinion or saying unless he knows where we took it from."66

Imam Malik said, "I am a human being and I can be right or wrong. So look at my opinion - if it is in conformity with the Qur'an and Sunnah take it, but if it is not in conformity with the Qur'an and Sunnah, leave it."67

Al-Shafi'i said, "If you find in my book things that do not conform to the Qur'an and Sunnah, do not take my opinion and abide by the Qur'an and Sunnah."68

Ibn Hanbal said, "Do not imitate me and do not imitate Malik, Abu Hanifah, al-Shafi'i, and al-Thawri, and you take from where they have taken."69

It is clear that the Islamic legal system has the power of review over the constitutionality or legitimacy of law, and subsequent articles will describe how the Islamic judiciary implemented or practiced this theory in a number of cases that are now considered among the most important implementations of this theory.

\section{Conclusion}

The review of the constitutionality of laws in the positive system only takes place in accordance with the rigid constitutions of states, which require special procedures for amendment. The supreme legality covers the whole system and is above the constitution itself. The text of the constitution is restricted by this legality, or the legality may take effect without the constitutional text if there is conflict in such a way that no reconciliation is possible The law that conflicts with these two would be unconstitutional and may be challenged for annulment, or through a plea of unconstitutionality depending on the prevalent system. The Islamic legal system has limited the powers of the ruler and made the rights of individuals a strong barrier in the face of these powers. As such, the Islamic legal system follows a substantive hierarchy of laws, where the legislative or executive authorities, or the head of the state, may not issue or promulgate a constitution, law or decree that is in contravention of any text in the Qur'an, Sunnah or consensus. This is called the review of conformity or compatibility which is primarily based on the conformity of a law, whatever its level, with the absolute text from the Qur'an, Sunnah or consensus, without regard to the level of the legislative text whether it is constitutional text or law. The Islamic legal system is in accord with positive legal systems in terms of the

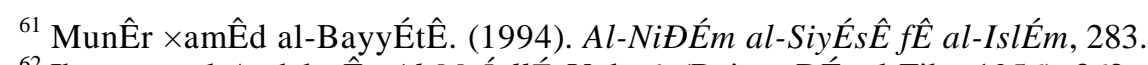

${ }^{62} \mathrm{Ibn} \times$ azm al-Andalusê, Al-MuÍallÉ. Vol. 6. (Beirut: DÉr al-Fikr, 1956), 362- 363.

${ }_{63}^{63}$ Al-Qur'Én 65: 1.

${ }^{64}$ Ibn ×azm al-Andalusê, Al-MuÍallÉ. Vol. 6. (Beirut: DÉr al-Fikr, 1956), 362.

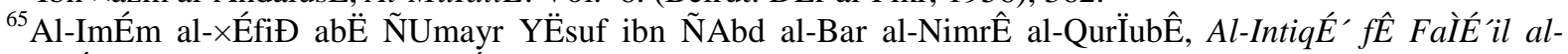
ThalÉthah al-A 'immah al-FuqahÉ'. (Cairo: Maktabat al-Quds, (n.d.) at 20.

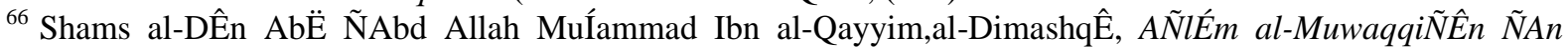
Rabb al-ÑÓlamÊn. Vol. 1. (Beirut: DÉr IÍyÉ' al-TurÉth al-ÑArabÊ, 1969), 302.

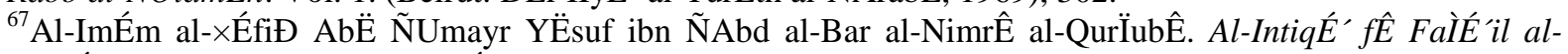
ThalÉthah al-A 'immah al-FuqahE', (n.d.). at 20.

${ }^{68}$ Ibid, 72

${ }^{69}$ YaÍlyÉ ibn Sharaf al-DÊn al-NawawÊ, Takmilat al-MajmË̃̃ Sharí al-Muhadhdhab. El-Medina Al-

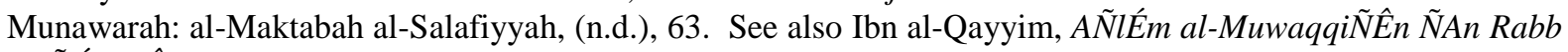
al-ÑólamÊn, (1969), 361. 
formal hierarchy of laws according to their strength. In the positive system, there is first the constitution, then laws, orders and regulations and lastly, individual rulings. In the Islamic legal system, the hierarchy can be found through the goals of the Shari'ah, and these are the indispensables, the necessary and the beneficial, hence the lower in rank may not contravene the ones above. The principle of sovereignty of law is the submission of the state, with all its institutions and individuals, to general and abstract rules that are stated beforehand and equally respected by both the rulers and the ruled. The principle of separation of power and authority, each with its own jurisdiction, has been applied in the Islamic legal system since the beginning of the Prophetic era, gradually becoming more apparent during the time of the caliph 'Umar ibn al-Khattab who applied the principle of separation of powers, as well as during the Umayyad era where this principle was well established. In analysing the principle of the independence of judicial authority in the Islamic legal system, it is noted that this system has applied the principle to a large extent, preceding the positive system in its application. Its importance arises as a result of its crucial role in the establishment of the principle of control over the constitutionality of laws in the Islamic system.

\section{REFERENCES}

[1] Al-ShÉÏibÊ, AbË IsíÉq. (1999). Al-muwÉfaqÉt fÊ usËl al-SharÊÑah. Vol. 1. Beirut: DÉr al-MaÑÉrif.

[2] Abdullah Yusuf Ali (trans.). (1984). The QurÑÉn, text, translation and commentary, Jedda: Islamic Education Center. Reprint by the Muslim Converts Association of Singapore.

[3] Al-ÑAwwÉ, MuÍammad SalÊm. (1983). FÊ al-niĐÉm al-siyÉsÊ li al-dawlah al-IslÉmiyyah. Cairo: al-Maktab al-MiÎrÊ al-×adÊth.

[4] Al-ÙamÉwÊ, SulaymÉn MuÍammad. (1976). Al-sulÏÉt al-thalÉth fÊ al-dasÉtÊr al-ÑArabiyyah wa fê al-fikr al-siyÉsê al-IslÉmÊ. Cairo: DÉr al-Fikr al-ÑArabÊ.

[5] ShaltËt, MaÍmËd. (1959). Al-IslÉm: ÑAqÊdah wa SharÊÑah. Kuwait: MaÏÉbiÑ DÉr al-Qalam.

[6] KhallÉf, ÑAbd al-WahhÉb. (1937). Al-sulïÉt al-thalÉth fÊ al-IslÉm: BaÍth fÊ mÉjallat al-qÉnËn wa al-iqtiÎÉd. Cairo.

[7] KhallÉf, ÑAbd al-WahhÉb. (1988). Al-siyÉsah al-SharÑiyyah. Kuwait: DÉr al-Qalam

[8] KhallÉf, ÑAbd al-WahhÉb. (1995). ÑIlm uÎ̈̈l al-fiqh wa khulÉÎat tÉrÊkh al-tashrỄ̃ al-IslÉmÊ. Cairo: DÉr al-Fikr alNArabÊ.

[9] Al-DirÊnÊ, Fatí̂̂E. (1987). KhấÉ'î̂ al-tashrÊÑ al-IslÉmÊ fÊ al-siyÉsah wa al-Íukm. (2nd ed.). Beirut: Mu'assasat alRisÉlah.

[10] Brown, Nathan J. (2002). Constitutional in a non constitutional world, (Arab basic laws and the prospects for accountable government). New York: State University of New York Press.

[11] Al-GhannËshÊ, RÉshid. (1993). Al-ÍurriyyÉt al-ÑÉmmah fÊ al-dawlah al-IslÉmiyyah. Beirut: Markaz DirÉsÉt alWiÍdah al-ÑArabiyyah.

[12] .Al-ShÉwÊ, TawfÊq. (1992). Fiqh al-shËrÉ wa al-istishÉrah. El-Mansura: DÉr al-WafÉ’’

[13] Al-BayyÉtÊ, MunÊr ×amÊd. (1994). Al-niĐÉm al-siyÉsÊ fÊ al-IslÉm: MuqÉran bi al-duwal al-qÉnËniyyah. (2nd Print). Amman: DÉr al-BashÊr.

[14] ÑAwdah, ÑAbd al-QÉdir. (1951). Al-Islam wa al-waìñiyyah al-qÉnËniyyah. Beirut: Mu'assasat al-RisÉlah.

[15] Al-MawdËdÊ, AbË al-AÑlÉ. (1985). TadwÊn al-dustËr al-IslÉmÊ. Saudi Arabia: DÉr al-SaÑ̈̈diyyah.

[16] Al-ImÉm al-xÉfiĐ, AbË ÑUmayr YËsuf ibn ÑAbd al-Bar al-NimrÊ al-Qurl̈ubÊ. (n.d.). Al-intiqÉ` fi falı́Éil althalÉthah al-a immah al-fuqahÉ'. Cairo: Maktabat al-Quds.

[17] Al-NawawÊ, YaÍyÉ ibn Sharaf al-DÊn. (n.d.). Takmilat al-majmËÑ sharÍ al-muhadhdhab. El-Medina Al-Munawarah: al-Maktabah al-Salafiyyah.

[18] AbË YËsuf YaÑqËb IbrÉhÊm. (1970). KitÉb al-kharÉj. Beirut: DÉr al-MaÑrifah.

[19] Al-BayhaqÊ, AÍmad ibn al-xusayn. (1980). Al-sunan al-kubrÉ. Vol. 10. Beirut: DÉr al-Fikr.

[20] Case 8, judicial Year 17, issued by the Supreme Constitutional Court 18 May, 1996.

[21] Egyptian Constitution of 1971 (Egypt)

[22] Farooq Hassan. (1981). The concept of state and law in Islam. London: University Press of America.

[23] Ibn ×azm al-AndalusÊ. (1956). Al-muÍallÉ. Vol. 6. Beirut: DÉr al-Fikr.

[24] Ibn al-Qayyim, Shams al-DÊn AbË ÑAbd Allah MuÍammad al-DimashqÊ. (1969). AÑlÉm al-muwaqqiÑ̂̂n Ñan Rab al-ÑÓlamÊn. Vol. 1. Beirut: DÉr IIIyÉ’ al-TurÉth al-ÑArabÊ.

[25] Islamic Computing Center, 73, St. Thomas's Road, London N4 2QJ.

[26] Sayyid Qü̈b. (1983). MaÑÉlim fÊ al-Ï̈arÊq. Beirut: DÉr al-ShurËq.

[27] Sunan al-NasÉ Ê: KitÉb al-qaléÉ'. (n.d.). (n.p.).

[28] Supperston, Michael and Goudie, James. (1992). Judicial review. London: Butterworths.

[29] Sunkin, Mourice and others. (1993). Judicial review in perspective. London: the Public Law Project.

[30] Ali Abd Al-Kader. (1984). “A review of Islamic culture.” The Islamic quarterly XXVIII (No. 1). England: the Islamic Culture Centre. 
[31] Ahmad Ibrahim. (1986). "The Shariah court and its place in the judicial system." International Islamic conference on the role of judiciary in the development of Islamic law. November 21- 23- Malaysia.

[32] Ali Abd Al-Kader. (1984). “A review of Islamic culture.” The Islamic quarterly XXVIII (No. 1). England: the Islamic Culture Centre.

[33] Anwar Ahmad Qadri.(1968). Justice in Historical Islam, Lahore: SH Muhammad Ashraf.

[34] Al-QÉsimÊ, ÚÉfir. (1974). NiĐÉm al-Íukm fÊ al-SharÊÑah wa al-tÉrÊkh al-IslÉmÊ: Al-sulÏah al-qaľ́ ‘iyyah. Beirut: DÉr al-NafÉ is.

[35] Al-×afnÉwÊ, ManÎËr MuÍammad. (1989). SulÏat al-dawlah fê al-manĐËr al-sharÑ̂̂. (1st ed.). Cairo: MaÏbaÑat alAmÉnah.

[36] Al-ÑAlkÊm, xasan. (1991). Al-niĐÉm al-siyÉsê al-IslamÊ: xiwÉr maÑa al-ÑalmÉniyyah. United Arab Emirates:Mu'assasat al-ÑAyn li al-TawzÊÑ wa al-Nashr.

[37] Sunan AbÊ DÉwËd. (2001). Beirut: DÉr al-Kutub al-ÑIlmiyyah.

[38] Muhammad Hashim Kamali. (1991). Principles of Islamic jurisprudence. (2nd ed.). Cambridge: Islamic Texts Sociry.

[39] Muhammad Hashim Kamali. (1993). "Appellate review and judicial independence in Islamic law." Chiblis Mallat and Graham Trotman (eds.). Islamic and public law. London: Graham \& Trotman.

[40] Al-QurÏubÊ, AbË ÑAbd al-Barr. (2002). Al-isÏî̂ÍÉb fÊ maÑrifat al-âl̂́Éb. Beirut: DÉr al-Kutub al-ÑIlmiyyah.

[41] BahnasÊ, AÍmad Fatî́E. (1984). Mawqif al-SharỄ̃ah min naĐariyyat al-difÉÑ al-ijtimÉñ̂̂. Beirut. DÉr al-ShurËq.

[42] Neumann, Michael. (2002). The rule of law, politicking ethics. England: Ashgate Publishing Limited.

[43] Al-MaÑhad al-ÑÓlamÊ li al-Fikr al-IslÉmÊ, Al-Dawlah: Al-Fikrah wa al-ArkÉn wa al-Mu'assasÉt. (U.S.A: Grove Street Herndon, 1981), 66-67.

[44] Al-Rayyis, ÖiyÉ' al-DÊn MuÍammad. (1976). Al-naĐariyyÉt al-siyÉsiyyah al-IslÉmiyyah. Cairo: Maktabat DÉr alTurÉth.

[45] MuÍammad YËsuf MËsÉ. (1964). NiĐÉm al-Íukm fÊ al-IslÉm. (2nd ed.). Cairo: DÉr al-KitÉb al-ÑArabÊ.

[46] Øaî́̂́I al-TirmidhÊ. (1997). Vol . 5. (1st ed.). Beirut: DÉr al-Kutub al-ÑIlmiyyah.

[47] Muslim, AbË al-xusayn ibn al-×ajjÉj al-NÊsÉbËrÊ. (n.d.). Øál̂̂́I Muslim. n.p.

[48] Muhammad Asad. (1980). The principles of state and government in Islam. Cibraltar: Dar al-Andalus.

[49] Al-MaÑhad al-ÑÓlamÊ li al-Fikr al-IslÉmÊ. (1981). Al-dawlah: Al-fikrah wa al-arkÉn wa al-mu’assasÉt. U.S.A: Grove Street Herndon.

[50] Ibn ×anbal, AÎ́mad. (1998). Al-musnad: Musnd al-anîÉr. Beirut: DÉr Ñólam al-Kutub.

[51] MuÍammad MuÍsin KhÉn. (trans.). (1970). Øaî́̂́Í al-BukhÉrÊ. Al-Medina al-Munauwara: Islamic University.

[52] Al-ÙibrÉnÊE, AbÊ al-QÉsim SulaymÉn ibn AÎ́mad. (1984). Al-muÑjam al-kabÊr. Vol. 13. Al-ÑIrÉq: IIIyÉ` al-TurÉth al-IslÉmÊ.

[53] Ibn HishÉm, AbË MuÍammad ÑAbd al-Malik. (1980). SÊrat al-NabÊ MuÍammad. Vol. 3. Cairo: Maktabat DÉr alTurÉth.

[54] AÍmad ×asan. (1969). "The political role of IjmÉÑ." Islamic studies: Journal of the Islamic research institute. Vol. VIII. No.1. Pakistan.

[55] Hassan Ibrahim Hassan. (1961). "Judiciary system from the rise of Islam to 567." The Islamic quarterly, a review of Islamic cultureVol. VI. No. 1 \& 2. .(1954). London: The Islamic Culture Centre.

[56] Coulson, N. J. (1956). "Doctrine and practice in Islamic law": Bulletin of the School of Oriental and African studies. Vol. XVIII. London: University of. London, Kraus Reprint Nendeln / Liechtenstein

[57] Hasan Masudul. (1988). Reconstruction of political thought in Islam. Pakistan: Islamic Publications (PVT) Limited.

[58] Tyan, Emile. (1955). "Judicial organization." Majid Khadduri (ed.). Law in Middle East. Vol.1, Washington, D.C: Middle East Institute.

[59] YÉsÊn ÑUmar YËsuf. (1995). IstiqlÉl al-sulÏah al-qaľéiyyah fê al-niĐÉmayn al-waİÑ̂̂ wa al-IslÉmÊ. (1st ed.). Beirut: DÉr wa Maktabat al-HilÉl.

[60] WakỄ̃, MuÍammad ibn Khalaf ibn xayyÉn. (2001). AkhbÉr al-quİÉt. (1st ed.). Beirut: ÑÓlam al-Kutub. 